\title{
Examining Financial Performance, Firm Size, Leverage and Corporate Social Responsibility
}

\author{
Dr. Fraser Nega* \\ Walden University \\ USA
}

\author{
Dr. Ify Diala-Nettles \\ Walden University \\ USA
}

\begin{abstract}
Approximately $\$ 25.2$ trillion in total assets under management is involved in some strategy of socially responsible and sustainable investing. Grounded in the stakeholder theory, the purpose of this correlational study was to examine the relationship between financial performance, firm size, leverage, and corporate social responsibility. A random sample included 119 large companies in the United States from the population of companies listed in the Russell 1000 index. The data were collected via Bloomberg Terminal. Multiple linear regression analysis was used to predict Environmental, Social \& Governance (ESG) activity scores. The 3 predictor variables accounted for approximately $7 \%$ of the variance in ESG activity scores and the result was statistically significant, $\mathrm{F}(3,115)=2.83, \mathrm{p}<.04, \mathrm{R} 2=.07$. Although the $\mathrm{p}$ value was significant, the R2 was low, thus representing a poor model fit. In the final analysis, total revenue was a significant predictor and was negatively correlated with ESG activity scores. However, return on equity and leverage were not significant predictors of ESG activity scores. This suggested the potential need to transfer some corporate social initiatives from business leaders to government policy makers. Future researchers should consider incorporating additional variables to make the model more useful. The results of this study are expected to identify fiscal incentives for corporate social programs that would benefit stakeholders such as employees, suppliers, customers, communities, and the environment.
\end{abstract}

Keywords — Financial Performance, Firm Size, Leverage, Corporate Social Responsibility, Bloomberg

\section{INTRODUCTION}

Corporate social responsibility (CSR) is a vital competitive strategy for all types of business organizations (Chandler \&Werther, 2013). Managers may improve competitiveness by engaging CSR strategies, based on the strengths of their companies (Nagurney \& Li, 2014). Implementing CSR strategies can transform a company's image and thus lead to a positive outlook among consumers, suppliers, and communities served by the company (Amma, Thaliyan \& Lekshimi, 2013). As thousands of companies in hundreds of countries participate in some level of CSR practices, research about CSR shifted from existential questions to the core business and contextual factors, processes, and related measures of financial and social findings (Tilt, 2016; Wang, Tong, Takeuchi, \& George, Dahlander, Graffin, \& Sim, 2016). Stakeholders may benefit from research that explains the relationship between financial performance, firm size, leverage, and CSR. This understanding may, in turn, lead to innovation, efficient logistics, employee motivation, positive publicity, and sustainability (Girerd-Potin, Jimenez, \& Louvet, 2014). Wang et al. (2016) highlighted the concept of CSR and the various factors pertaining to organizational purpose, with a call for additional research to inform academics and managerial leadership on business elements related to the transformative roles of businesses in contemporary society.

\section{PROBLEM \& PURPOSE OF THE STUDY}

Financial performance, firm size, and leverage may influence CSR (Maskun, 2013). In 2011, approximately $\$ 3.74$ trillion of the $\$ 25$ trillion of investment assets in the United States was financed via socially responsible activities-a $22 \%$ increase since 2009 (Elliot, Jackson, \& Peecher, 2014). The general business problem was that business leaders may lack adequate knowledge to understand the implications of CSR on the financial performance of their businesses (Wang et al., 2016). The specific business problem was that some business leaders in the United States do not understand the relationship between financial performance, firm size, leverage and CSR. The purpose of this quantitative correlational study was to examine the relationships between financial performance, firm size, leverage, and CSR. The predictor variables were financial performance, firm size, and leverage. The criterion variable was environmental, social and governance (ESG) activity scores. The population for this study comprised American publicly traded corporate firms listed in the Russell 1000 Index. The implications for positive social change included the need for government policy makers to investigate the potential need and means to implement regulations and financial incentives to increase the scale and prominence of CSR activities that may benefit employees, customers, the environment, and members of society. 


\section{DISCUSSIONS}

The following three null and alternative hypotheses, which aligned with the three predictor variables and the single criterion variable in the overarching research question:

H1o. There is no statistically significant relationship between financial performance and CSR.

H1a. There is a statistically significant relationship between financial performance and CSR.

H2o. There is no statistically significant relationship between firm size and CSR.

$\mathrm{H} 2 \mathrm{a}$. There is statistically significant relationship between firm size and CSR.

H3o. There is no statistically significant relationship between leverage and CSR.

$\mathrm{H} 3 \mathrm{a}$. There is a statistically significant relationship between leverage and CSR.

\section{A. Corporate Social Responsibility}

CSR has become an increasingly important part of companies' operations (Deng, Kang, \&Low, 2013). Many businesses increased their investment in CSR activities and some firms dedicated large portions of their annual reports to present their CSR activities (Flammer, 2013). At the end of 2011, \$3.74 trillion of the \$25 trillion of investment assets went toward socially responsible investment initiatives (Elliot, Jackson, \& Peecher, 2014). The growing importance of corporate social investments by American firms led to questions about why business leaders integrate CSR into their business strategies, especially in light of the prior research that revealed mixed evidence for a relationship between CSR and financial performance (Wang et al., 2016). American companies increasingly involved in CSR initiatives reported two major reasons for CSR investments, competition, and profit growth (Flammer, 2015). The history of defining CSR dated back to Freeman (1984) who advanced the idea that in the process of profit-maximization, firms should do right by their employees, customers, the environment, and local communities. Freeman's work pertained to the duties associated with good corporate citizenship. To build on Freeman's work, Solomon and Hanson (1985) suggested that addressing social responsibility is good for investors, as well as other stakeholders. Solomon and Hanson expanded the view of stakeholders to include (a) customers, (b) employees, (c) communities, (d) public interest groups, and (e) government agencies or regulators. Decades later, scholars, such as Kirat (2015), focused on the idea of CSR as involving the maintenance of a high standard of living for stakeholders while increasing profits for organizations. The various definitions provided by scholars are pertinent to the three essential dimensions of CSR: environmental, social, and governance (Wang et al., 2016). Multiple terms emerged from the academic literature as synonymous or associated with CSR, such as (a) social responsibility, (b) corporate social performance, (c) corporate citizenship, (d) sustainability, (e) global business citizenship, (f) corporate governance, (g) corporate accountability, (h) corporate community engagement, and (i) business commitment (Ioannou \& Serafeim, 2015; Luu, 2013; Tribó et al., 2012). Early work with stakeholder theory and CSR had significant philosophical implications (Flammer, 2013; Van Limburg et al., 2015). However, the new theoretical approaches to CSR extended beyond the previous narrow focus toward a combined framework that includes operational and behavioral aspects of companies' integration with their outside environments (Wang et al., 2016). The traditional role of business leaders is facing a challenge due to growing demands of societies (Schmelz, 2014). Companies rarely act as separate entities operating with minimum attention to society (Wang et al., 2016). In the past, business leaders created strategies that enabled them to maximize profits and outperform their competitors (John, 2014). Business leaders had no plan to listen to other stakeholders as outside regulators closely monitored companies' day-to-day activities to protect the environment and members of communities (Flammer, 2013). Business leaders became more enthusiastic in embracing voluntary self-regulations to address the social and environmental goals (Javaid, Ali, \& Khan, 2016), and from a growing demand to incorporate the stakeholders' interest into the companies' business strategies (Van Limburg et al., 2015). According to Filatotchev and Nakajima (2014), CSR initiatives provided opportunities for business leaders to convert resources into goods and services while creating additional value for stakeholders. Successful leadership is required to promote companies' corporate citizenship (Lindgreen et al., 2012 Luu, 2013). Business leaders incorporate CSR as an integral part of the decision-making process (Jones, Mackey, \&Whetten, 2014). Jones et al. (2014) furthered the idea that the adoption of CSR within a company requires progressive leadership approach; progressive leaders are enablers and inspire a shared vision, which involves motivation, empowering employees towards a greater good that serves stakeholders. Jones et al. noted that the implementation of progressive leadership strategies requires business leaders to commit to their roles in facilitating employee motivation, team building, diversity, equal employment, ethics, and financial transparency. Another aspect of CSR involves maintenance of adequate corporate governance and control (Yusoff, Dalila, Jamal, \& Darus, 2016). Jo and Harjoto (2011) noted that CSR is an extension of companies 'efforts to foster effective corporate governance to ensure sustainability via sound business practices that promote accountability and financial transparency. Adequate corporate governance and controls build trusts with stakeholders through positive public relations and high ethical standards to minimize business and legal risks and maximize responsible actions. The social responsibility actions may include community development, environmental protection, customer satisfaction, and philanthropy, creating shared value, social education and awareness, and product safety (Wang et al., 2016). Philanthropy involves charitable activities by companies to share benefits with the communities and the environment in which these companies operate (Mair \& 
Hehenberger, 2014; Tilcsik \& Marquis, 2013). Corporate philanthropic activities include the donation of funds, goods, and services to serve the social and environmental welfare programs (Yusoff et al., 2016). Growing expectations by the customers and communities may lead to increased corporate philanthropy (Sahota, 2013). Corporate philanthropy is one of the most distinguishing factors between stockholder theorists who suggest profit maximization as the sole responsibility of a manager and stakeholder theorists who advance corporate citizenship (Yusoff et al., 2016). Active participation of a manager in corporate philanthropy promotes the wellbeing of the communities and may enhance stakeholders' satisfactions (Wang et al., 2016). In so doing, companies may attract new consumers and increase their prospects of future profitability (Koschate-Fischer et al., 2012; Lindgreen et al., 2012; Metcalf et al., 2013). Managers may use corporate philanthropy to expand and promote marketing programs and build positive reputations, which is an important intangible business firm asset (George et al., 2016). Basera (2013) noted that in the last few decades, CSR became a broad concept with a focus on environmental concerns, attraction of customers, service to communities, and treatment of employees. A review of the literature showed that six of the major essential elements of corporate social responsibilities are addressing and benefiting (a) the environment, (b) customers, (c) communities, (d) employees, (e) marketplace, and (f) government. Traditionally, the role of business manager was to generate profits for the sole purpose of enhancing shareholder value (Basera, 2013). Baker (2004) and Paul and Lee (2007) explained the transition toward social responsibility as stemming from both a moral responsibility as well as a strategic resource essential to increase financial performance.

\section{B. Relationship Between Financial Performance and CSR}

Despite numerous studies by scholars, the relationship between financial performance and CSR remains questionable (Lu, Chau, Wang, \&Pan, 2014). The empirical study authored by Bidhari, Salim, and Aisjah (2013) involved the effects of CSR information disclosure on financial performance and firm value in banking. Bidhari et al. selected 15 banking firms listed at ISE, based on population criteria with observation of secondary data obtained from annual reports and financial statements from 2008 to 2011. Bidhari et al. applied path analysis method to analyze the data that revealed CSR information disclosure affects all financial performance measurements, namely return on assets, return on equity, and return on sales. This empirical research was relevant to this doctoral study in its examination of the potential link between CSR and financial performance. The study's findings indicated compelling argument as to which variables are appropriate to examine the relationship between CSR and financial performance. Similarly, Ofori, Nyuur, and Darko (2014) reviewed the impact of CSR on financial performance based on empirical evidence from the Ghanaian banking sector. The study included a sample of 22 banks and a structured questionnaire to obtain primary data and used secondary sources for additional numerical data (Ofori et al., 2014). The research findings revealed that banks in Ghana consider CSR practice as a strategic tool and Ofori et al. concluded there could be a positive relationship between CSR and financial performance. However, the financial performance of banks in Ghana depends significantly on other control variables such as growth, debt ratio, origin, and size (Ofori et al., 2014). This research also has relevance to the primary research question of my study, which is an inquiry about a relationship between CSR and financial performance. The possible relationship between CSR and financial performance is the subject of the first hypothesis of this study.

\section{Firm Size Measurements}

Firm size is the second predictor variable proposed for this study. Firm size is an important variable because large companies may promote CSR strategies more often than small firms. Inclusion of the concept of firm size may lead to additional insights about a relationship that may exist between firm size and CSR. As detailed in previous sections, financial performance and CSR were the subjects of previous research. However, relatively few researchers examined the possibility of a relationship between firm size and CSR. According to Udayasankar (2008), small and medium-sized firms consist of 90 percent of the global number of companies; unlike large firms, small firms have limited capital and operational capacities that may limit CSR activities.

\section{Relationship Between Firm Size and CSR}

Firm size is an element applied to explain economies of scale in production, advertising, capital market, and profitability applied (Shalit \& Sankar, 1977). Some factors determine firm size; according to Dang and Lee (2013), the two most popular theories applied to determine firm size are technological theories and organizational theories. The size of a firm tends to be large when longer chains of production process organized within the boundaries of the company. Technological theorists postulate that as technology grows fast, the size of a firm declines. A practical example of this theory observed in the manufacturing sector. Continuous investments in technology may reduce the need for hiring more workers because, as the company transitions from labour-intensive to capital-intensive practices, leaders begin to hire only small and highly skilled number of employees (Mohamad \& Ismail, 2013). Sun, Shen, Cheng, \& Zhang (2015) examined the Chinese manufacturing sectors to determine the relationship between firm size and factor intensity. The study's findings indicated that firms in more capital-intensive industries are larger than those industries that are more labour-intensive. Technological theories focus on the production process and emphasize physical capital and economies of scale and scope as variables that determine the optimal 
firm size and ultimately profitability. Organizational theorists have linked size and profitability with organization structure, agency cost, and span of control. Organizational theorists noted that most small businesses are sole proprietorships or partnerships, while large firms are corporations or public companies managed by managers (Kirkland, 2015). In a corporate business structure, an elected board of directors oversees the firm with the appointment of executive staff to manage the company (Eesley et al., 2015). The executives manage the daily activities of the company and directly responsible for implementing corporate strategies, although market demand tends to drive managerial activities as well as technologyinnovation achievements (Zou, Guo, \& Guo, 2016). Orlitzky (2001) conducted a meta-analysis of the relationship between firm size and corporate social performance, as well as CSR and financial performance. The study's results indicated that metaanalysis indicated a weak correlation between firm size and corporate social performance, whereas CSR and financial performance may have a stronger positive relationship (Orlitzky, 2001). A limitation of the study was the meta-analytical approach, but the study is relevant to the research question and provides an insight to support the ongoing study of CSR and firm size. Understanding the configuration of firm characteristics in studying CSR findings is also important. Udayasankar (2008) examined the relationship between CSR and firm size, including the different economic motivations of businesses with varying combination of visibility, resource access, and scale of operations included in the examination. Udayasankar's results indicated that visibility, resource access, operating scale, and firm size lead to active social responsibility participation. The research outcome, however, revealed a U-shaped relationship between firm size and CSR, implicating other factors that may lead to active CSR, in addition to the size of a firm. Similarly, Lepoutrue and Heene (2006) examined firm size and CSR. Lepoutrue and Heene reviewed the impact of firm size on four major antecedents of business characteristics: (a) issue characteristics, (b) personal characteristics, (c) organization characteristics, and (d) context characteristics. Lepoutrue and Heene revealed that size does not impose barriers on CSR activities. However, smaller firm CSR activity depended on conditions such as (a) availability of resources, (b) the influence of external stakeholders, (c) negotiation power, and (d) socioeconomic conditions (Lepoutrue \& Heene, 2006). Scholars such as Wang et al. (2016) suggested continuing the study of CSR considering previous research that filled the peer-reviewed literature but that may not be as relevant to the changing contexts of businesses in society due to the passage of time. A logistic regression analysis in a more recent study by Ozcelik, Ozturk, and Gursakal (2014) revealed no relationship between CSR and financial performance, but indicated the possibility of a positive relationship between CSR and company size. In this study, Ozcelik et al. selected a sample from the top 100 firms from Istanbul Stock Index, who adopted CSR between 2010 and 2012. CSR was the dependent variable and financial performance, firm size, risk, and type of ownership were independent variables (Ozcelik et al., 2014). Although there was a significant relationship between company size and CSR for the sample in Istanbul, analysis did not indicate any relationship between financial performance, risk, type of ownership, and CSR. The application of the accounting-based financial measurement metrics to measure financial performance and the data analysis methodology used make it relevant to this study. Additionally, research results might differ among industries, sectors, and operating locations based on differences in regulatory, cultural, and political climates, which are limitations to the generalizability of Ozcelik et al.'s findings.

\section{E. Relationship Between Leverage and CSR}

Leverage in finance refers to the use of debt to finance or fund investments (Zhu et al., 2014). The use of debt to fund their operations is a common practice by most business companies and can be a good business strategy if managers use it efficiently. Understanding the implication of leverage can help investors and the company (Zhu et al., 2014). The prudent use of debts by a manager may increase profitability; however, if companies use too much debt to finance operations, and the investment did not go well, the company may face significant risks, as leverage affects future funding opportunities (Serrano-Cinca, GutiérrezNieto, \& López-Palacios, 2015). The risks include substantial interest expense and default risk may reduce shareholders' value. In this study, leverage is one of the three predictor variables, which represent a new model for the view of CSR activities. Orlitzky and Benjamin (2001) studied the relationship between CSR and financial risks. Orlitzky and Benjamin examined the relationship between corporate social performance and financial performance and hypothesized that strong corporate social performance could reduce financial risks. Orlitzky and Benjamin distributed a survey to the top-level managers of 655 corporations and applied descriptive statistics and regression to analyze the responses. Orlitzky and Benjamin reported a relationship between corporate social performance and risk that appeared to be one of reciprocal causality. Implication of the study by Orlitzky and Benjamin included the idea that a higher corporate social performance may lead to lower financial risks. In another study, Maskun (2013) explored the impact of leverage, company size, and profitability on disclosure of CSR of 15 LQ-45 companies in the Indonesian Stock Exchange from 2009 through 2011. Maskun applied multiple linear regression models to measure the impact of leverage, company size, and profitability on CSR disclosure. Results reported by Maskun indicated companies with significant profit size maintained CSR disclosures. In regard to company size and leverage, the results indicated large companies tended to have better CSR disclosures and high leverage levels had a significant positive impact on CSR disclosures of the Indonesian companies (Maskun, 2013). 


\section{METHODOLOGY}

The objective of this quantitative study was to determine whether a significant relationship exists between financial performance, firm size, leverage, and CSR. In this study, secondary archival data sources were used and it did not involve human subjects. The appropriate way to examine the relationship was the use of a quantitative methodology and multiple regression analysis using secondary datasets. The use of secondary data from the Bloomberg database for this study involved searching the well-publicized, publicly available, free financial database. The specific sample data for this research came from the Russell 3000 index, composed of the largest 3000 U.S. public companies (Malenko \& Shen, 2016). SPSS Version 21 software was used to facilitate analysis of large datasets. A quantitative research method involves logical formation and examination of research questions, hypothesis testing, and determination of relationships among known variables. The research design for this study was correlational. The correlational design was suitable for the study of possible relationships among known quantifiable variables. In this study, financial performance, firm size, and leverage were the predictor variables and ESG activity scores was the criterion variable. The population consisted of companies in the top five Russell Global Sectors that include financial, technology, health care, consumer discretionary, and producer durables. According to Mertens (2014), sampling of the population is the extraction of subsets from the general frame to examine characteristics. The sample from the population in quantitative studies leads to an opportunity to infer characteristics to the entire population. The general population was U. S. publicly traded companies listed in the Russell index by the end of 2015. A random sampling technique was suitable for quantitative research, resulting in a high level of inferential precision without studying every element of the population (Bryman \& Bell, 2015). In this study, there was an assumption that a random sample of the population is generalizable to the larger population with a predefined confidence level. In a systematic random sampling technique, the companies in the population received a number. It was determined the sample interval size $(k)$ by dividing the number in the population $(N)$ by the number in the sample $(n)$, predetermined by using G*Power3 statistical software. For this study, G*Power's F-test regression for linear multiple regression. The F-test regression test requires selecting and justifying an established effect size of $.02, .15$, and .35 for small, medium, and large, respectively. A power analysis, using G*Power3 Version 3.1 .9 software conducted to determine the appropriate sample size for the study. A priori power analysis which contained three predictor variables using a medium effect size $(f=.15), \alpha=.05$, and F-test linear multiple regression indicated a minimum sample size of 77 firms was sufficient to achieve a power of .80, and a maximum sample size of 119 firms to achieve a power of .95. Therefore, in this study, a total sample size of 119 firms was obtained.

\section{FINDINGS \& RESULTS}

\section{Inferential Statistical Results}

The regression analysis summary table for predictor variables (Table 1) contains the standardized regression equation coefficients for the relationships between financial performance, firm size, leverage and CSR. The standardized $\beta$ coefficients indicate by how much the dependent variable is expected to increase or decrease for a unit change in the independent variable in comparison with standardized coefficients of the other predictor variables.

Table 1

Regression Analysis Summary for Predictor Variables

\begin{tabular}{lcccccc}
\hline Variable & $\mathrm{B}$ & $\mathrm{SE} B$ & $\beta$ & $t$ & $p$ & Bootstrap 95\% CI (M) \\
\hline ROE & .06 & -09 & .06 & .67 & .50 & $-.12-.22$ \\
Total Revenue & -.56 & .12 & -.26 & -2.87 & .01 & $-.90--.22$ \\
Leverage & -.01 & .02 & -.04 & -.40 & .69 & $-.04-.04$ \\
\hline
\end{tabular}

Note. $N=119 ; \mathrm{B}=$ unstandardized coefficient; $\beta=$ standardized coefficient

Standard multiple linear regression was used, $\alpha=.05$ (two-tailed), to examine the relationship between financial performance, firm size, leverage, and corporate social responsibility. The predictor variables were financial performance, firm size, and leverage. The criterion variable was CSR ESG activity scores. The central research question pertained to the significance of the relationship between financial performance, firm size, leverage, and corporate social responsibility. The following research hypotheses reflected the research question:

H1o. There is no statistically significant relationship between financial performance and CSR.

H1a. There is a statistically significant relationship between financial performance and CSR. 
$\mathrm{H} 2 \mathrm{o}$. There is no statistically significant relationship between firm size and CSR.

$\mathrm{H} 2 \mathrm{a}$. There is statistically significant relationship between firm size and CSR.

H3o. There is no statistically significant relationship between leverage and CSR.

$\mathrm{H} 3 \mathrm{a}$. There is a statistically significant relationship between leverage and CSR.

The model was adequate to significantly predict ESG activity scores, $F(3,115)=2.83, p<.04, R^{2}=.07$. The low $R^{2}(.07)$ value indicated that the linear combination of the predictor variables (ROE, total revenue and leverage) was an explanation for approximately $7 \%$ of the variations in ESG activity scores. In the final analysis, the predictor variable total revenue was statistically significant to explain the variation in ESG activity scores with $(\beta=-.26, t=-2.87, p<.01)$. The other predictor variables $\operatorname{ROE}(\beta=.06, t=.67, p>.50)$ and leverage $(\beta=-.04, t=-.40, p>.69)$ did not explain any significant variations in ESG activity scores. Based on the statistical significance of the predictor variable (total revenue), I could reject the respective null hypothesis. Based on the statistical insignificance of the other two predictor variables (ROE and leverage), I could not reject their respective null hypotheses. The final predictive equation was:

$$
\text { ESG Activity Score }=33.65+.06 \text { ROE }-.56 \text { Total Revenue }-.01 \text { Leverage }
$$

Total Revenue. There is a statistically significant negative relationship between firm size and corporate social responsibility. The negative slope for total revenue (-.56) as a predictor variable of ESG activity scores indicated that there was about a .56 decrease in ESG activity scores for each 1-point increase in total revenue. The squared semipartial coefficient $\left(s r^{2}\right)$ that is an estimate of how much variance in ESG activity scores was uniquely predictable from total revenue was .07, indicating that total revenue accounts for $7 \%$ of the variance in ESG activity scores, after controlling for the effects of ROE and leverage.

ROE. There is no statistically significant relationship between financial performance and corporate social responsibility. The positive slope for ROE (.06) as a predictor variable of ESG activity scores indicated that there was about a .06 increase in ESG activity scores for each 1-point increase in ROE. The squared semipartial coefficient $\left(s r^{2}\right)$ that estimated how much variance in ESG activity scores was uniquely predictable from ROE was less than .01, indicating that ROE accounts for less than .10\% of the variance in ESG activity when controlling for total revenue and leverage are controlled.

Leverage. There is no statistically significant relationship between leverage and corporate social responsibility. The negative slope for leverage (-.01) as a predictor variable of ESG activity scores indicated that there was about a .01 decrease in ESG activity scores for each 1-point increase in leverage. The squared semipartial coefficient $\left(s r^{2}\right)$ that was an estimate of how much variance in ESG activity scores was uniquely predictable from leverage was less than .01, indicating that leverage accounts for less than $.1 \%$ of the variance in ESG activity scores when controlling for ROE and total revenue.

The following conclusions pertain to the results of the null and alternative hypotheses. First, financial performance measured by ROE does not have a significant relationship with corporate social responsibility measured by ESG activity scores and does not support the stakeholder theory. Second, firm size measured by total revenue has a significant statistical negative relationship with corporate social responsibility, measured by ESG activity scores. Third, leverage does not have a significant relationship with corporate social responsibility, measured by ESG activity scores.

\section{CONCLUSION}

The findings in this study have two vital implications. First, in spite of the findings of this study, business leaders should continue to integrate corporate social programs as long as business leaders justify that investing in these programs could yield positive results to various stakeholders of the company. Secondly, corporate social responsibility should not be the sole responsibility of business leaders. Government institutions should continue to have active roles in promoting CSR initiatives as long as they find these CSR initiatives relevant to promoting the wellbeing of the society. Beyond the debate on the relationship between financial performance and corporate social responsibility, researchers need to understand how corporate social program modify the behavior of stakeholders including business leaders, investors, suppliers, customers, employees and the community. Business leaders need to understand that socially responsible investment is efficient and sufficient to achieve the objective of greater ethical and social responsibility in an organization. 


\section{REFERENCES}

[1] Amma, K. S., Thaliyan, D., \& Lekshmi, J. (2013). A study on the common imperatives organization require for creating productive employees: Creating $6(2)$,

a perspective to the expression of authentic self as a new challenge to the global business management International Journal of Global Business,

90-110. Retrieved from http://www/gsmi-ijgb.com/

[2] Baker, M. (2004). CSR: What does it mean? Retrieved from http://www.mallenbaker.net

[3] Basera, H. C. (2013). Internal CSR: A key tool for competitiveness in the retail small to medium enterprise sector in Masvingo, Zimbabwe. International Journal of Management Science and Business Research, 2(10), 72-80. Retrieved from http://www.ijmsbr.com

[4] Bidhari, S. C., Salim, U., \& Aisjah, S. (2013). Effect of CSR information disclosure on financial performance and firm value in banking industry listed at Indonesia stock exchange. European Journal of Business and Management, 5(18), 39-46. Retrieved from http://www.iiste.org

[5] Bryman, A., \& Bell, E. (2015). Business research methods. Oxford, UK: University Press.

[6] Chandler, D. B., \& Werther, W. B. (2013). Strategic CSR: Stakeholders, globalization, and sustainable value creation. Thousand Oaks, CA: Sage Publications

[7] Deng, X., Kang, J. K., \& Low, B. S. (2013). CSR and stakeholder value maximization: Evidence from mergers. Journal of Financial Economics, 110(1), 87-109. doi:10.1016/j. jfineco.2013.04.014

[8] Eesley, C. E., DeCelles, K., \& Lenox, M. (2015). Through the mud or in the boardroom: Activist types and their coercive strategies in targeting firms for social change. Social Science Research Network, 1(1), 1-28. doi:10.2139/ssrn.2574046

[9] Elliot, W. B., Jackson, K. E., \& Peecher, M. E. (2014). The unintended effect of CSR performance on investors' estimates of fundamental value. The Accounting Review, 89, 275-302. doi:10.2308/accr-50577

[10] Filatotchev, I., \& Nakajima, C. (2014). Corporate governance, responsible managerial behavior, and CSR: Organizational efficiency versus organizational legitimacy? Academy of Management Perspectives, 28, 289-306. doi:10.5465/amp.2014.0014

[11] Flammer, C. (2013). Corporate social responsibility and shareholder reaction: The environmental awareness of investors. Academy of Management Journal, 56, 758-781. doi:10.5465/amj.2011.0744

[12] Freeman, R. E. (1984). Strategic management: A stakeholder approach. New York, NY: Cambridge University Press.

[13] George, G., Dahlander, L., Graffin, S., \& Sim, S. (2016). Reputation and status: Expanding the role of social evaluation in management research. Academy of Management Journal, 59, 1-13. doi:10.5465/amj.2016.4001

[14] Girerd-Potin, I., Jimenez-Garces, S., \& Louvet, P. (2012). Which dimensions of social responsibility concern financial investors? Journal of Business Ethics, 121, 559-576. doi:10.1007/s10551-013-1731-1

[15] Ioannou, I., \& Serafeim, G. (2015). The impact of CSR on investment recommendations: Analysts' perceptions and shifting institutional logics. Strategic Management Journal, 36, 1053-1081. doi:10.1002/smj.2268

[16] Javaid L. E., Ali, A., \& Khan, I. (2016). Corporate governance and CSR disclosure: evidence from Pakistan. The International Journal of Business in Society, 16, 785-797. doi:10.1108/CG-05-2016-0100

[17] Jo, H., \& Harjoto, M. A. (2011). Corporate governance and firm value: The impact of corporate social responsibility. Journal of Business Ethics, 103, $351-$ 383. doi:10.1007/s10551-011-0869-y

[18] John, A. G. (2014). Market orientation, organizational learning capabilities and strategic competitiveness: An inquiry into the causes of sustaining competitive success. International Business Research, 7, 179-186. doi:10.5539/ibrv7n10p179

[19] Jones C., L., Mackey, A., \& Whetten, D. (2014). Taking responsibility for CSR: The role of leaders in creating, implementing, sustaining, or avoiding socially responsible firm behaviors. Academy of Management Perspectives, 28(2), 164-178. doi:10.5465/amp.2012.0047

[20] Kirat, M. (2015). CSR in the oil and gas industry in Qatar perceptions and practices. Public Relations Review, 41, 438-446. doi:10.1016/j. pubrev.2015.07.001

[21] Kirkland, S. (2015). Helping S corporations avoid unreasonable compensation audits.

[22] Koschate-Fischer, N., Stefan, I., \& Hoyer, W. (2012). Willingness to pay for cause- related marketing: The donation amount and moderating effects. Journal of Marketing Research, 49, 910-927. doi:10.1509/jmr.10.0511

[23] Lindgreen, A., Xu, Y., Maon, F., \& Wilcock, J. (2012). Corporate social responsibility brand leadership: A multiple case study. European Journal of Marketing, 46, 965-993. doi.10.1108/03090561211230142

[24] Luu, T. T. (2013). Corporate social responsibility, leadership, and brand equity in healthcare service. Social Responsibility Journal, 8 , 347-362. doi:10.1108/17471111211247929

[25] Lu, W., Chau, K. W., Wang, H., \& Pan, W. (2014). A decade's debate on the nexus between corporate social and corporate financial performance: A critical review of empirical studies 2002-2011. Journal of Cleaner Production, 79, 195-206. doi:10.1016/j. jclepro.2014.04.072

[26] Mair, J., \& Hehenberger, L. (2014). Front-stage and backstage convening: The transition from opposition to mutualistic coexistence in organizational philanthropy. Academy of Management Journal, 57, 1174-1200. doi:10.5465/amj.2012.0305

[27] Malenko, N., \& Shen, Y. (2016). The role of proxy advisory firms: Evidence from a regression-discontinuity design. Oxford, England: Oxford University Press. doi:10.1093/rfs/hhw070

[28] Maskun, A. (2013). Leverage level, company size, profitability toward the disclosure of CSR of LQ-45 companies in Indonesia stock exchange. International Journal of Academic Research, 5,140-144. doi:10.7813/2075- 4124.2013/5-2/B.21

[29] Mohamad, R., \& Ismail, N. A. (2013). The extent of E-business usage and perceived cumulative benefits: A survey on small and medium-sized enterprises.

Information Management and Business Review, 5, 13-19. Retrieved from http://www.ifrnd.org

[30] Nagurney, A., \& Li, D. (2014). A dynamic network oligopoly model with transportation costs, product differentiation, and quality competition 
International Journal of Computer Applications Technology and Research

Volume 7-Issue 02, 78-85, 2018, ISSN:-2319-8656

Computational Economics, 44, 201-229. doi:10.1007/s10614-013-9387-6

[31] Ofori, D. F., Nyuur, R. B., \& Darko, M. D. (2014). CSR and financial performance: Fact or fiction? A look at Ghanaian Banks. Acta Commercii, 4(1), 111. doi:10.4102/ac. v14i1.18

[32] Orlitzky, M. (2001). Does firm size confound the relationship between corporate social performance and firm financial performance? Journal of Business Ethics, 33, 167-180. doi:10.1023/A:1017516826427

[33] Orlitzky, M., \& Benjamin, J. D. (2001). Corporate social performance and firm risk: Ameta-analytic review. Business and Society, 40, $369-396$. doi: $10.1177 / 000765030104000402$

[34] Ozçelik, F., Avci Oztürk, B., \& Gürsakal, S. (2014). Investigating the relationship between CSR and financial performance in Turkey. Ataturk University Journal of Economics and Administrative Sciences, 28, 189-203. Retrieved from http://www.e-dergi.atauni.edu.tr

[35] Sahota, A. (2013). CSR and philanthropy. Sustainability: How the cosmetics industry is greening up. Chichester, United Kingdom: John Wiley \& Sons Ltd.

[36] Schmeltz, L. (2014). Identical or just compatible? The utility of corporate identity values in communicating CSR. Journal of Business Communication, 51,234-258. doi:10.1177/2329488414525439

[37] Serrano-Cinca, C., Gutiérrez-Nieto, B., \& López-Palacios, L. (2015). Determinants of Default in P2P Lending. PLoS ONE, 10(10), 1-22. doi:10.1371/journal. pone.0139427

[38] Shalit, S. S., \& Sankar, U. (1977). The measurement of firm size. Review of Economics and Statistics, 59, 290-298. Retrieved from http://www.jstor.org

[39] Solomon, R. C., \& Hanson, K. R. (1985). It's good business. New York, NY: Atheneum.

[40] Sun, X., Shen, H., Cheng, X., \& Zhang, Y. (2016). Market confidence predicts stock price: Beyond supply and demand. PLoS ONE, 11 (7), 1-10. doi:10.1371/journal.pone.0158742

[41] Tilcsik, A., \& Marquis, C. (2013). Punctuated generosity: How mega-events and natural disasters affect corporate philanthropy in U.S. communities. Administrative Science Quarterly, 58, 111-148. Retrieved from http://www.hdl.handle.net

[42] Tilt, C. (2016). Corporate social responsibility research: The importance of context. International Journal of Corporate Social Responsibility, 1, 2-7. doi:10.1186/s40991-016-0003-7

[43] Tribó, J. A., Torres, A., Bijmolt, T. H., \& Verhoef, P. (2013). Generating global brand equity through corporate social responsibility to key stakeholders. International Journal of Research in Marketing, 29, 13-24. doi:101016/j.ijresmar.2011.10.002

[44] Udayasankar, K. (2008). CSR and firm size. Journal of Business Ethics, 83(2), 167-175. doi:10.1007/s10551-007-9609-8

[45] Van Limburg, M., Wentzel, J., Sanderman, R., \&Van Gemert-Pijnen, L. (2015). Business modeling to implement an eHealth portal for infection control: A reflection on co-creation with stakeholders. JMIR Research Protocols, 4(3), 104-119. doi:10.2196/resprot.4519

[46] Wang, H., Tong, L., Takeuchi, R., \& George, G. (2016). CSR: An overview and new research directions. Academy of Management Journal, 59, 534-544. doi:10.5465/amj.2016.5001

[47] Yusoff, H., Dalila A., Jamal, A., \& Darus, F. (2016). Corporate governance and corporate social responsibility disclosures: An emphasis on the CSR key dimensions. Journal of Accounting and Auditing, 2016, 476-550. doi:10.5171/2016.476550

[48] Zou, B., Guo, F., \& Guo, J. (2016). Absorptive capacity, technological innovation, and product life cycle: A system dynamics model. SpringerPlus, 5, 1662-1675. doi:10.1186/s40064-016-3328-5 